\title{
Nomenclatural changes in heterocytous Cyanoprokaryotes (Cyanobacteria, Cyanophytes)
}

\author{
Jiří KOMÁREK \\ Institute of Botany AS CR, Dukelská 135, CZ-37982 Třebon̆, Czech Republic
}

\begin{abstract}
The criteria for systematic classification of Cyanoprokaryota (Cyanobacteria, Cyanophyta) were changed considerably in last decades. The molecular and morphological analyses, ecological characterization and biochemical markers are indispensable premises for modern cyanobacterial taxonomic re-classification. Many genera were divided, newly described and numerous species were transferred in generic entities, characterized on the basis of molecular, ecological and revised morphological criteria. All of the proposed taxonomic changes are included in the manuscript of the recently prepared $3^{\text {rd }}$ volume of "Cyanoprokaryotes" in the frame of the new edited compendium Süsswasserflora von Mitteleuropa" ( $2^{\text {nd }}$ edition, volume 19/3, Heterocytous genera). The used taxonomic status of many taxa is already clearly revised in numerous modern publications, but in several cases the nomenclatural consequences were not yet validly published (new combinations, few new names of taxa). However, it is necessary to publish validly the corrected names before edition of any monographic review. The valid nomenclatural transfer of 9 species, one new name and description of two species, the changed position of which follows without doubts from the recent modern revisions, are therefore included in the present article. The validation is published in agreement with the last edition of Botanical Nomenclatoric Code (ICBN; MCNeILL et al., ed. 2007). All the mentioned species belong to the heterocytous monophyletic group Nostocales (or Nostochineae, respectively), and are arranged alphabetically.
\end{abstract}

Key words: Cyanoprokaryotes, Cyanobacteria, Cyanophyceae, taxonomy, nomenclature, new combinations, new taxa

\section{Introduction}

The following nomenclatural transfers are necessary to the elaboration of the taxonomic review of heterocytous cyanobacteria in the third volume of cyanoprokaryotes in the frame of the new edition of Süsswasserflora von Mitteleuropa (vol. 19/3, Heterocytous genera, subcl. Nostochineae). The argumentation and comments are added to all discussed taxa. Ten taxonomic transfers are included in the article (in one case connected with creation of a new name), and two new species, not yet validly described, are defined in coincidence with botanical nomenclatoric rules (MCNeILL et al. ed. 2007). The re-named species are arranged alphabetically.

\section{Results and Discussion}

Anabaena ellipsoidea (COMPÈre 1967) comb. nov. (Fig. 2)

[Basionym: Anabaena sphaerica var. ellipsoidea
COMPÈRE, Bull. Jard. Bot. Nat. Belg. 37(2): 151, 247. 1967].

Comments: Numerous subspecific taxa were described in A. sphaerica, which differ in form of akinetes without transient types. A. sphaerica var. ellipsoidea is morphologically distinctly different and recognizable from typical $A$. sphaerica. Ecology and taxonomy of both taxa (A. sphaerica and $A$. ellipsoidea) should be verified and studied in future.

\section{Chrysosporum minor (KISELEV 1927) comb. nov. (Fig. 1)}

[Basionym: Anabaena bergii var. minor KIselev, Izv. Vsesoj. Nauch.-issled. Inst. Ozer. Rechn. Ryb. Chozj., Lenningrad, 5(2): 279, 1927; Syn.: Anabaena bergii f. minor (Kiselev) Elenkin, Monogr. Alg. Cyanoph., pars spec. 1: 672, 1938].

Comments: The species Anabaena bergii OsteNFELd 1908 and its var. minor KiseLEv 1927 
are similar morphologically, but they differ clearly in dimensions and ecology. Besides, they do not occur in identical habitats and should be considered as various taxa. The status variety or form is unclear and commonly not accepted in the modern cyanobacterial taxonomy. Both mentioned taxa are probably slightly divergent in position in phylogenetic trees (cf. STÜKEN et al. 2009) and therefore should be separated as different species. Chrysosporum minor has smaller dimensions as An. bergii (recently re-combined also to Chrysosporum by ZAPOMĚLOVÁ et al. 2012) and occurs mostly in plankton of extreme, inland salinic water bodies. Typical $A$. bergii occurs in eutrophic reservoirs in tropical and warm regions, and its distribution was recorded originally in Africa, Central Asia and Eastern Europe, but in last decades probably expands and has been recorded also in numerous localities in Central Europe. $A$. bergii var. (or f.) minor was cited several times also from new localities, but both taxa should be checked in future. - Anabaena bergii was recently re-classified into the new established genus Chrysosporum (ZAPOMĚLOVÁ et al. 2012) as a type species of this new genus, according to the results of molecular and polyphasic studies of StÜKEn et al. (2009) and ZAPOMĚLovÁ et al. (2012). Because A. bergii f. minor belongs to the same phylogenetic group, it must be transferred also into the genus Chrysosporum.

Cyanospira globosa (HIRANo 1963) comb. nov. (Fig. 3)

[Basionym: Anabaena globosa HiRano, Contr. Biol. Lab. Kyoto Univ. 16: 4, 1963].

Comments: Anabaena globosa was described from Afghanistan by HirAno (1963) and not confirmed later. It is therefore only little known, but the diacritical characters (solitary living trichomes, planktic life form, presence of gas vesicles in cells, apoheterocytic origin of akinetes in long rows) correspond clearly to the diacritical features of the genus Cyanospira Florenzano et al. 1985 and must be transferred to this genus.

\section{Cylindrospermopsis gangetica (NAIR 1967) comb. nov. (Fig. 4) \\ [Basionym: Anabaenopsis gangetica NAIR, Hydrobiologia 30(1): 147, 1967; Syn.: Cylindrospermopsis curvispora M. WatanaBe, Bull. Natur. Sci. Mus., Tokyo, ser. B, 21(2): 48, 1995].}

Comments: Several types with spherically coiled trichomes, terminal heterocytes and one or two sausage-like akinetes situated just aside "inner" heterocytes in coiled trichomes were described in the planktic genus Cylindrospermopsis. Akinetes develop directly from one or two neighboring cells to heterocytes or distant from heterocytes by 1-3 vegetative cells. C. gangetica and C. curvispora are both characterized by long, cylindrical cells, $3.5-7 \times 1.5-2.8 \mu \mathrm{m}$ and occur in Japan, India and possibly also in S Africa. The publication of Nair (1967) has priority against the name "curvispora M. WATANABE 1995" and must be therefore recombined into the genus Cylindrospermopsis. Very similar type was found in Srí Lanka and Southern Africa, but with distinctly shorter, barrel-shaped cells and distinct constrictions at cross-walls. This type was provisionally named "Cylindrospermopsis allantoidispora" by KoMÁRKovÁ \& AzEVEDo 1998 (which is, however, still "nomen nudum"). If both taxa are genetically and taxonomically identical or different, must be resolved by further studies.

\section{Cylindrospermum longisporum sp. nov.}

\section{(Fig. 5)}

[Syn.: Cylindrospermum sp. 1 sensu KomÁRek, Nova Hedwigia 26: 619, 1975].

Diagnosis: Filamenta solitaria vel in coloniis microscopicis. Trichomata recta vel paucim flexuosa, cylindrica, in dissepimentis constricta, ad apices non attenuata. Cellulae cylindricae, distincte longiores quam latae, contentu pallide aeruginoso vel lutescente-viridi, sepe keritomico, $4-11 \times \pm 3 \mu \mathrm{m}$; cellula terminalis cylindrica et rotundata. Heterocyta terminales, cylindrica vel longe ovoidea, 11-17 × 4.5-6 um. Akinetes cylindricae, solitariae, cum exosporio laevi sine colore, 24-43 × 7-10.6 $\mu \mathrm{m}$.

Locus classicus: In paludis prope piscinam Řežabinec, prope oppidum Písek, Bohemia meridionalis.

Type (iconotype): КомÁREK 1975, l.c. Fig. 6:3.

Description: Filaments solitary or in microscopic colonies. Trichomes \pm straight or slightly flexuous, cylindrical, not attenuated at the ends, constricted at cross-walls. Cells cylindrical, clearly longer than wide, pale blue-green or yellowish, usually keritomized, $4-11 \times \pm 3 \mu \mathrm{m}$. Terminal cells cylindrical and rounded at the end. Heterocytes terminal, cylindrical or long-ovoid, $11-17 \times 4.5-6$ $\mu \mathrm{m}$. Akinetes cylindrical, solitary, with smooth colourless exospore, $24-43 \times 7-10.6 \mu \mathrm{m}$. - In 
marshes and wet meadows, partly submersely; orig. locality: Czech Republic, South Bohemia, meadows near the pond Řežabinec.

Comments: Cylindrospermum longisporum with distinct morphology and ecology was presented and documented firstly in KomÁreK (1975) and designated as "Cylindrospermum sp." However, this morphotype was several times found in similar localities. It cannot be classified in any other described Cylindrospermum species and its description is therefore justifiable. The diacritical features are morphology of vegetative cells and akinetes, position and form of akinetes, dimensions and ecology.

\section{Cylindrospermum paludicola sp. nov. (Fig. 6)}

[Syn.: Cylindrospermum sp. 2 sensu KoмÁreK, Nova Hedwigia 26: 619-620, 1975.]

Diagnosis: Filamenta tagetes aeruginosas vel olivaceas formantia. Trichomata paucim flexuosa, cylindrica, in dissepimentis paucim constricta. Cellulae cylindricae, aeruginosae vel griseo-aeruginosae, plus minusve isodiametricae vel longiores quam latae, 1.6-7 × 2.2-3 $\mu \mathrm{m}$. Cellulae terminales conicae vel cylindricae, apice rotundatae. Heterocyta ovoidea vel cylindrica, externis rotundata, 4.8-8 × 2.8-4.5 $\mu \mathrm{m}$. Akinetes cylindricae, ovales, solitariae vel ad 3-seriatae, 12-36 × 7-11.5 um, cum exosporio laevi, brunescente.

Locus classicus: Ad terram inundatam et in fossis et stagnis cum fondo arenoso, prope piscinam Řežabinec, prope oppidum Písek, Bohemia meridionalis.

Type (iconotype): Komárek 1975, l.c., Fig. 4:3.

Descriptions: Filaments in blue-green or olive green mats. Trichomes slightly flexuous, cylindrical, slightly constricted at cross-walls. Cells cylindrical, blue-green or grey-blue, \pm isodiametric or longer than wide, 1.6-7 $\times 2.2-3$ $\mu \mathrm{m}$. Terminal cells conical or cylindrical and rounded. Heterocytes ovoid to cylindrical with rounded ends, $4.8-8 \times 2.8-4.5 \mu \mathrm{m}$. Akinetes oval cylindrical, solitary up to 3 in a row, 12-36 x 7-11.5 $\mu \mathrm{m}$, with smooth, brownish exospore. - On wet soils, sometimes among mosses and in pools with sandy bottom, distributed in northern parts of temperate zone in Europe and North America.

Comments: The morphotype of C. paludicola was published originally as Cylindrospermum sp. 2 by KoMÁREK (1975), and later under different names by other authors. This species was recorded later several times under various names. It represents a specific taxon with distinct ecology. Diacritical features are dimensions, morphology and characteristic ecology.

\section{Hapalosiphon cossyrensis (BoRzì 1907) comb. nov. (Fig. 7)}

[Basionym: Sommierella cossyrensis BoRzì, Atti Congr. Nat. Ital., Milano, 1907.]

Comments: The genus Sommierella (with only one species $S$. cossyrensis) is insufficiently described. However, this species was studied by KOMÁREK \& Rosa (1957) from similar habitats and the vegetative stages corresponded fully to the genus Hapalosiphon. There does not exist any character, according to which can be separated the genus Sommierella from young stages of Hapalosiphon. The species does not correspond to any other Hapalosiphon species.

\section{Petalonema incrustans (KüTZING 1849) comb. nov. (Fig. 8)}

[Basionym: Scytonema incrustans KüTzING, Phyc. Gener., p. 216, 1843 ex Bornet et Flahault, Ann. Sci. Nat. VIII. Bot. 5: 107, 1887.]

Comments: The genus Petalonema needs further studies, but if we accept it according to modern classification of scytonematacean cyanobacteria, the taxon "Scytonema incrustans" should be transferred into this genus. It is surely different from Scytonema crustaceum AgardH ex Bornet et Flahault to which was sometimes classified as a taxonomic variety. Particularly the type of branches is different, without any transitional modifications.

\section{Trichormus indicus stat. et nom. nov.}

\section{(Fig. 9)}

(Syn.: Anabaena vaginicola f. fertilissima PRASAD, J. Ind. Bot. Soc. 31: 361, 1952; = typus; Fig. 14-17 1.c. = icona typica).

Diagnosis: Filamenta libera vel in vaginis mucilaginosis, diffluentibus disposita; coloniae pallide virides. Trichomata aeruginosa, flexuosa, in dissepimentis constricta, ad apices paucim attenuata. Cellulae plus minusve quadraticae, barriliformes, 3.2$5.6 \times 4.8-5.6 \mu \mathrm{m}$; cellulae terminales conice-acutae. Heterocyta barriliformes, intercalares, 5.5-6 × 6.6-7.2 $\mu \mathrm{m}$. Akinetes in seriebus longis, ellipsoidales, 11.2$13.4 \times 6.4-8 \mu \mathrm{m} .-$ Bentice in fluviis; locus classicus: 
flumen Barma, prope Benaras, India.

Comments: The Prasad's variety (1952) differs distinctly from Anabaena vaginicola and belongs also in another genus. The typical An. vaginicola was transferred to the genus Wollea by R.N. SingH (1942), "f. fertilissima" belongs evidently into the genus Trichormus (akinetes develop in long chains). The transfer on the species level is therefore necessary. The epithet "fertilissima" is not possible to use in respect to Trichormus fertilissimus (RAO) KomÁREK et ANAGNOSTIDIS 1989, based on Anabaena fertilissima RAO 1937.

\section{Trichormus kashiensis (BHARADWAYA 1935) comb. nov. (Fig. 10) \\ (Basionym: Anabaena kashiensis Bharadwaya, Proc. Indian Acad. Sci. 2(1): 105, 1935.)}

Comments: Originally described as Anabaena, but with morphological characters of the genus Trichormus, mainly with apoheterocytically developing akinetes in long rows. Described from India.

\section{Trichormus portoricensis (GARDNER 1927) comb. nov. (Fig. 11)}

(Basionym: Anabaena portoricesis GARDNER, Mem. New York Bot. Gard. 7: 61, 1927.)

Comments: Corresponding to the genus Trichormus (apoheterocytically developing long rows of wide oval to almost spherical akinetes) by diacritical features. Known from Caribbean district, Puerto Rico (original description) and Cuba (KoMÁREK 2005).

\section{Trichormus tenuis (G.S.WEST 1907) comb. nov.} (Fig. 12)

(Basionym: Nodularia tenuis G.S.WEST, J. Linn. Soc. Bot. 38: 171, 1907.)

Comments: T. tenuis does not correspond to the definition of the genus Nodularia, but it was not yet transferred from this genus. According to morphological characters, especially apoheterocytic rows of akinetes, it belongs to the genus Trichormus.

\section{Acknowledgements}

This nomenclatural paper was elaborated in the frame of the grant support AVOZ60050516. I thank to managing editor of Fottea, Prof. Dr. A. Poulíčková, for publication of this nomenclatural article which is necessary for validation of cited taxa, and to reviewers, particularly to Dr. Z. Pouzar (Prague) for numerous corrections and remarks to the text.

\section{References:}

AnAgnostidis, K. (2001): Nomenclatural changes in cyanoprokaryotic order Oscillatoriales. - Preslia 73: 359-375.

Bharadwaya, Y. (1935): The Myxophyceae of the United Provinces, India I. - Proc. Indian Acad. Sci. B 2: 95-107.

Compère, P. (1967): Algues du Sahara et de la région du lac Tchad. - Bull. Jard. Bot. Nat. Belg., Bruxelles, 37: 109-288.

Elenkin, A.A. (1936-1938): Monographia Algarum Cyanophycearum Aquidulcium et Terrestrium in Finibus URSS Inventarum. Pars Specialis (Systematica), 1. - 984 pp., Acad. Sci URSS Moscow.

Florenzano, G.; Sili, C.; Pelosi, E. \& Vicenzini, M. (1985): Cyanospira rippkae and Cyanospira capsulata (gen. nov. and spp. nov.): new filamentous heterocystous cyanobacteria from Magadi lake (Kenya). - Arch. Microbiol. 140: 301-306.

Gardner, N.L. (1927): New Myxophyceae from Porto Rico. - Mem. NY Bot. Garden 7: 1-144.

Geitler, L (1932): Cyanophyceae. - In: Rabenhorst's Kryptogamenflora von Deutschland, Österreich und der Schweiz 14.-1196 pp.,Akad. Verlagsges., Leipzig.

Hirano, M. (1963): Fresh water algae from the Nepal Himalaya, collected by a member of the Japanese Climbing Expedition. - Contr. Biol. Lab., Kyoto Univ., Japan, 16:1-23.

Hollerbach, M.M.; Kossinskaja, E.K. \& PoljanskiJ, V.I. (1953): Sinezelenye vodorosli [Bluegreen algae.]. - In: Opredelitel presnovodnych vodorostej SSSR 2. - 652 pp., Sovetskaja Nauka, Moscow.

Kiselev, I.A. (1927): Novye dannye o vodorosljach Araĺskogo morja. [New data about algae of Aral Sea.] - Izv. Vsesoj. Nauch.-issled. Inst. Ozer. Rechn. Ryb. Chozj., Leningrad 5:1-64.

KomÁREK, J. (1975): Blaualgen aus dem Naturschutzgebiet „Řežabinec“ bei Ražice.Nova Hedwigia 26: 601-643.

KomÁrek, J. (2005): Studies on the Cyanophytes (Cyanobacteria, Cyanoprokaryota) of Cuba: (11) Freshwater Anabaena species. - Preslia 77: 211-234. 
KomÁreK, J. \& Rosa, K. (1957): Nález sinice Sommierella cossyrensis BORZI (?) v Čechách. [Das Vorkommen der Blaualge Sommierella cossyrensis Borzi (?) in Böhmen.] - Preslia, Praha, 29: 17-27. [Czech, German summary.]

KomÁrkovÁ, J. (1998): The tropical planktonic genus Cylindrospermopsis (Cyanophytes, Cyanobacteria). - In: Azevedo M.T.P. (ed.): Ann. IV ${ }^{\text {th }}$ Latino-Amer. Phycol. Congr. - pp. 327-340, São Paulo, Brasil.

Kosinskaja, E.K. (1926): De Petalonemate, sectione Scytonematis, monographia. - Notulae Syst. Inst. Crypt. Horti Bot. Principalis U.S.S.R. 4: $59-75$

KütZing, F.T. (1843): Phycologia generalis oder Anatomie, Physiologie und Systemkunde der Tange. -458 pp., Leipzig.

NAIR, G.U. (1967): The Nostocaceae of Kanpur - II. Hydrobiologia 30: 145-153.

McNeill, J.; Barrie, F.R.; Burdet, H.M.; Demoulin, V.; Hawksworth, D.L.; Marhold, K.; Nicolson, D.H.; Prado, J.; Silva, P.C.; Skog, J.E.; Wiersema, J.H. \& Turland, N.J. (ed.)(2007): International Code of Botanical Nomenclature (Vienna Code). Regnum Vegetabile 146. A.R.G. Gantner Verlag KG. ISBN 0080-0694

Ostenfeld, C.H. (1908): Phytoplankton aus dem Victoria Nyanza. - Engler's Bot. Jahrb. 41: 330-350.

Prasad, B.N. (1952): Some Nostacaceae from Uttar Pradesh. - J. Indian Bot. Soc. 31: 358-361.

SingH, R.N. (1942): Wollea bharadwajae sp. nov. and its auto-ecology. - Ann. Bot. 6: 593.

Starmach, K. (1962): Glony żyjące na ściezkach w nadrzecnych wierzbinach (Algae found growing in foot paths in willow thickets near the Mszanka and Raba rivers, Polish Western Carpathians). Fragm. Florist. Geobot. 8: 81-88.

Stüken, A.; Campbell, R.J.; Quesada, A.; Sukenik, A.; DAdheEch, P.K. \& Wiedner, C. (2009): Genetic and morphologic characterization of four putative cylindrospermopsin producing species of the cyanobacterial genera Anabaena and Aphanizomenon. - J. Plankton Res. 31: 465-480.

Watanabe, M. (1995): Studies on the planktonic blue-green algae. 5. A new species of Cylindrospermopsis (Nostocaceae) from Japan. - Bull. Nat. Sci. Mus., Ser. B. 21: 45-48.

West, G.S. (1907): Report on the Freshwater Algae, including Phytoplankton, of the Third Tanganyika Expedition conducted by Dr. W. A. Cunnington. - J. Lin. Soc. Bot. 38: 395-432.

Whelden, R.M. (1947): Algae. - In: Polunin N. (ed.): Botany of Canadian eastern Arctic, II. Thallophyta and Bryophyta. - Bull. Nat. Mus. Can. 97: 13-127.

Zapomělová, E.; Skácelová, O.; Pumann, P.; Kopp,
R. \& JANEČEK, E. (2012): Biogeographically interesting planktonic Nostocales (Cyanobacteria) in the Czech Republic and their polyphasic evaluation resulting in taxonomic revisions of Anabaena bergii OSTENFELD 1908 (Chrysospermum gen. nov.) and A. tenericaulis NygAARD 1949 (Dolichospermum tenericaule comb. nova). - Hydrobiologia (submitted). 


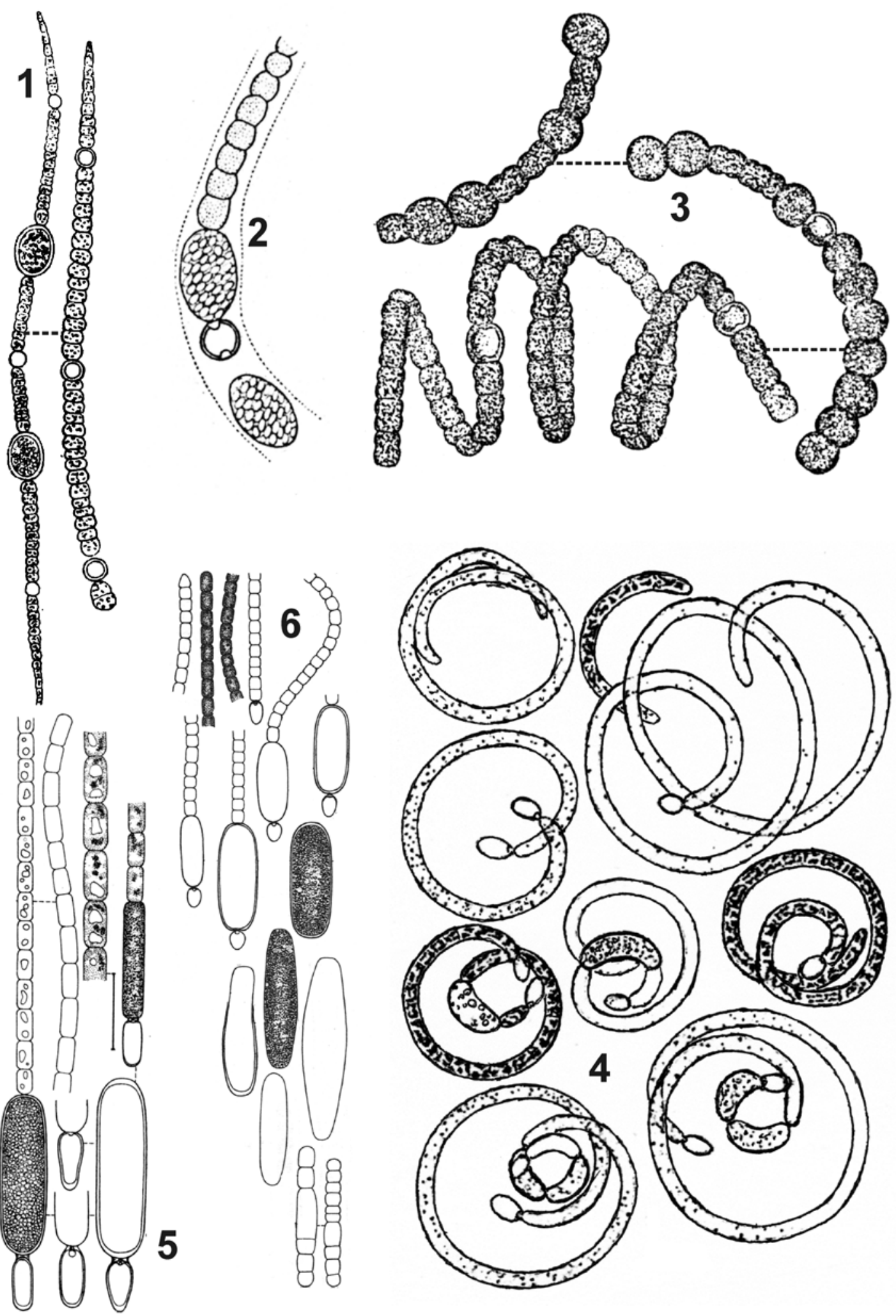

Fig. 1. Chrysospermum minor: after Ostenfeld from Hollerbach et al. (1953), sub. Anabaena bergii var. minor.

Fig. 2. Anabaena ellipsoidea: after COMPÈre (1967), sub Anabaena sphaerica var. ellipsoidea.

Fig. 3. Cyanospira globosa: after HiRANo (1963), sub Anabaena globosa.

Fig. 4. Cylindrospermopsis gangetica: after NAIR (1967), sub Anabaenopsis gangetica.

Fig. 5. Cylindrospermum longisporum: after KомÁreK (1975), sub Cylindrospermum sp. 1.

Fig. 6. Cylindrospermum paludicola: after KомÁreк (1975), sub Cylindrospermum sp. 2. 


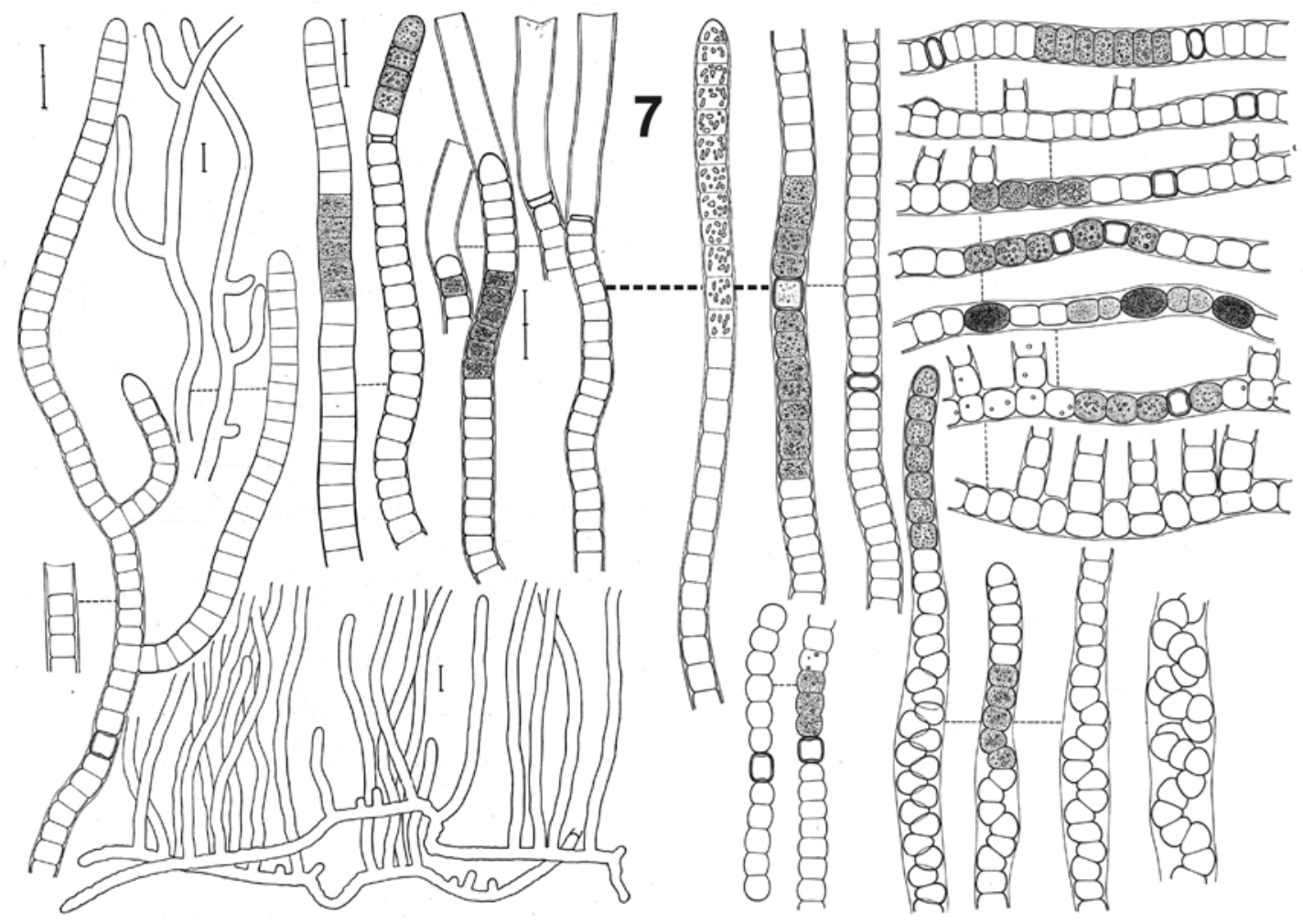

$\mathbf{h}$

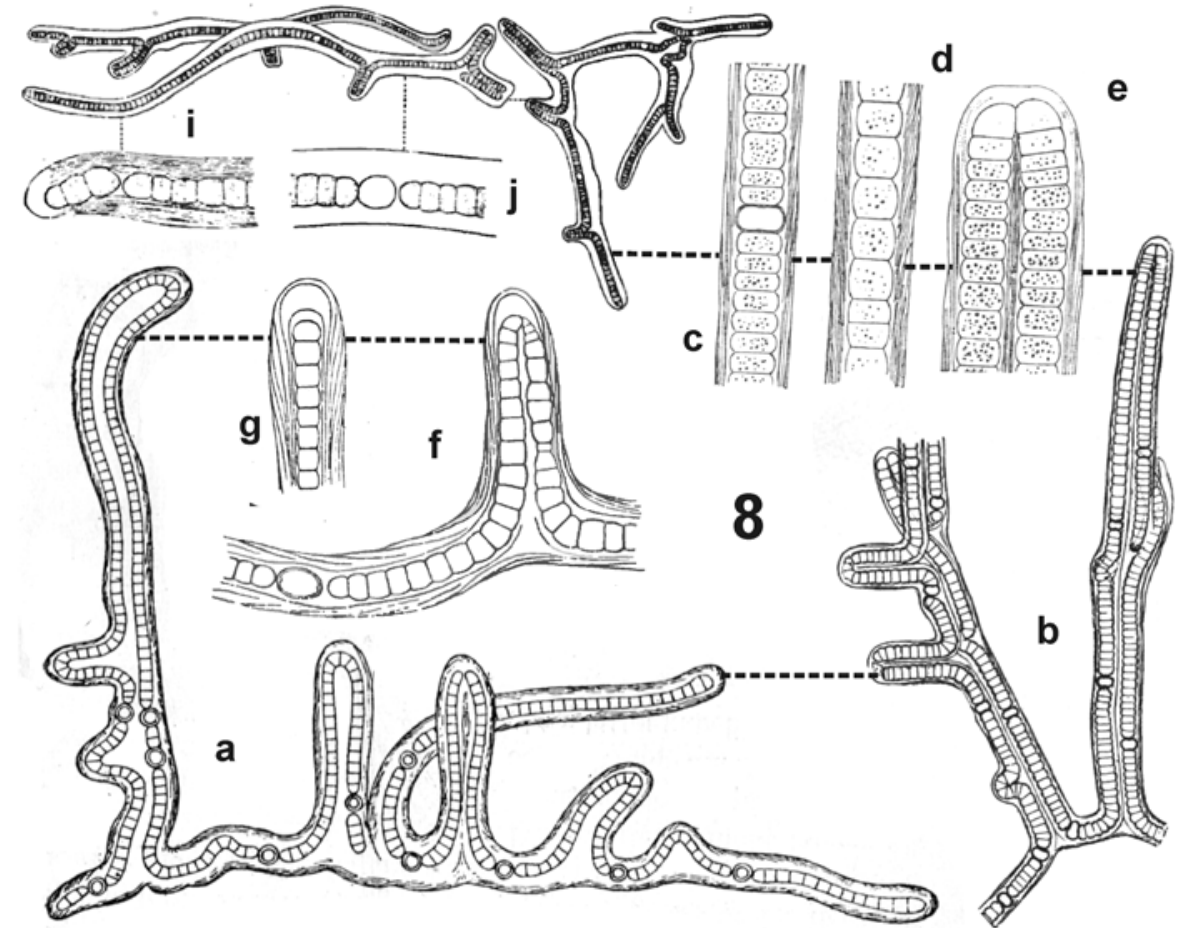

Fig. 7. Hapalosiphon cossyrensis: after KoMÁREK \& RosA (1957), sub Sommierella cossyrensis.

Fig. 8. Petalonema incrustans: (a) after Kosinskaja (1926); (b-e) after Geitler (1932); (f-g) after Starmach (1962); (h-j) after WHELDEN (1947); sub Scytonema crustaceum var. incrustans. 


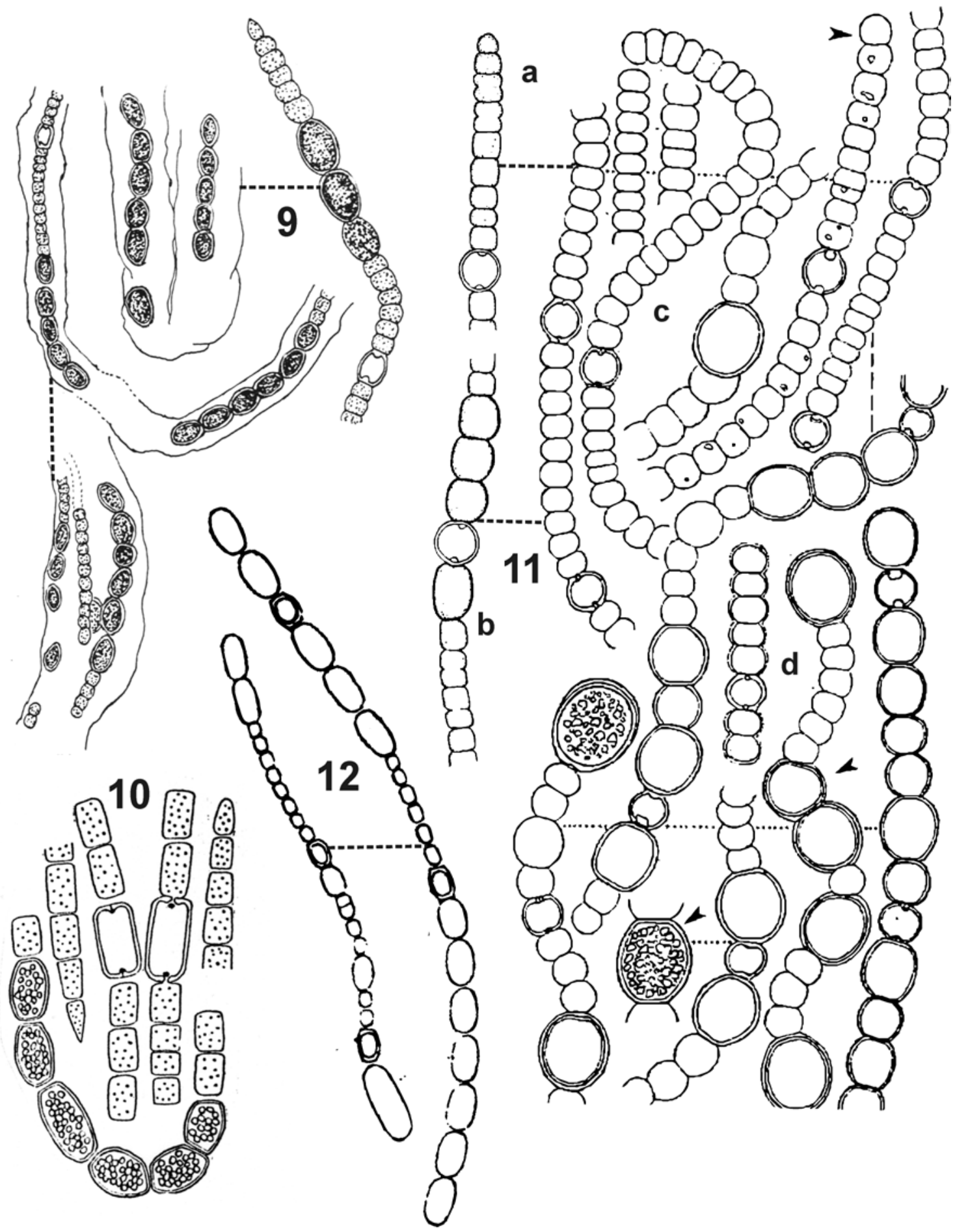

Fig. 9. Trichormus indicus: after PRASAD (1952), sub Anabaena vaginicola var. fertilissima.

Fig. 10. Trichormus kashiensis: after Bharadwaya (1935), sub Anabaena kashiensis.

Fig. 11. Trichormus portoricensis: (a-b) after GARDNER (1927); (c-d) after KOMÁREK (2005). sub Anabaena portoricensis. . Fig. 12. Trichormus tenuis: after G.S.WeSt (1907), sub Nodularia tenuis.

(C) Czech Phycological Society (2012)

Received May 15, 2011

Accepted September 20, 2011 